\title{
Is The Enemy Us?
}

\section{New Threats To Privacy, Freedom Of Information And Civil Liberties In The Age Of Terrorism}

\author{
Richard S. Rosenberg \\ Department of Computer Science, The University of British Columbia, \\ Vancouver, BC Canada V6T 1 Z4 \\ rosen@cs.ubc.ca
}

\begin{abstract}
A number of events have taken place in Canada and the U.S. following the terrorist attacks of September 11, 2001. These events include both proposed and enacted legislation, actions taken to deal with immediate and perceived threats to nations and their inhabitants, and limitations in existing civil liberties, that may or may not be warranted. The title of this paper is taken in part from the much lamented cartoon Pogo, in which Pogo admits, "I have seen the enemy and he is us." The first part of this paper deals with an analysis of the proposed Anti-terrorist Act, Bill C-36, introduced by the federal government of Canada in October and November of 2001. A sampling of criticism and issues of special concern are presented with special attention to the impact on the online world. The second part deals with parallel legislation, the USA PATRIOT Act, signed into law by President Bush at the end of October, 2001. Because of concern that the Internet had been used by terrorists to plan and coordinate their heinous acts, it has received special attention.
\end{abstract}

\section{INTRODUCTION}

"The struggle to establish civil liberties against the backdrop of these security threats, while difficult, promises to build bulwarks of liberty that can endure the fears and frenzy of sudden danger-bulwarks to help guarantee that a nation fighting for its survival does not sacrifice those national values that make the fight worthwhile." [1]

The original version of this chapter was revised: The copyright line was incorrect. This has been corrected. The Erratum to this chapter is available at DOI: 10.1007/978-0-387-35609-9_29 
The greatest test for democracies, such as ours, is how they behave, and by they I mean both the government and the governed of Canada and the U.S.A., in times of national emergencies such as we find ourselves. In this regard, consider the words of Justice William J. Brennan, Jr., the noted U.S. Supreme Court judge, in the above quotation.

A number of important events have taken place in Canada and the U.S. following the terrorist attacks of September 11, 2001. These events include both proposed and enacted legislation, actions taken to deal with immediate and perceived threats to the nations and their inhabitants, and limitations in existing civil liberties, that may or may not be warranted. The title of this paper is taken in part from the much lamented cartoon Pogo, in which Pogo admits, "I have seen the enemy and he is us." Well, in a literal sense, we are not the enemy but if in response to a series of steps being taken by our governments we do not react with sufficient energy and commitment to defend our liberties, then indeed, we are our own enemy!

The first part of this paper deals with an analysis of the Anti-terrorist Act, Bill C-36, introduced by the federal government of Canada in October and November of 2001, and given Royal Assent in December, following the terrorist attacks on September 11, 2001. The basic premise underlying this legislation was that the terrible attacks required a clear and comprehensive response by Canada, and of course the U.S. and elsewhere. Furthermore, it would be necessary to compromise certain, long accepted civil liberties in order to increase the level of security demanded as a result of terrorist actions. Simply put, such a valued right as personal privacy might have to be weakened in order to strengthen national security. While there exists some sympathy for this proposition, its execution arouses a deep concern in those committed to a continuance of the basic civil liberties so integral to our democratic societies. A sampling of criticism and issues of special concern are presented with special attention to the impact on the online world.

The second part deals with parallel legislation, the USA PATRIOT Act, signed into law by President Bush at the end of October, 2001. This massive Act has implications, yet to be fully understood. Of concern as well, are a number of steps taken by the Bush Administration, to deal with non-U.S. citizens suspected of terrorist activities. These include trial by military tribunals, suspension of confidentiality of lawyer-client communications, and even a serious consideration of torture in certain circumstances or the extradition of suspects to their home countries, where torture to obtain confessions is often practiced. However, these issues are beyond the direct concern of this paper.

Because of the widely-held belief that the Internet had been used by terrorists to plan and coordinate their heinous acts, it has received special attention. Long held expectations of free speech and privacy on the Internet 
are under attack. Indeed, these expectations were in fact frequently illusory but the new legislation explicitly delineates the actual limitations and characterizes the new powers of law enforcement officials. Such attacks on long held civil liberties should be met with resistance in those cases that clearly do not merit their use. Just because something can be done is no reason that it should be done.

\section{BILL C-36, THE ANTI-TERRORISM ACT}

First reading of Bill C-36 [2] took place on October 15, 2001 ${ }^{1}$. It is described as an Act to amend the Criminal Code, the Official Secrets Act, the Canada Evidence Act, the Proceeds of Crime (Money Laundering) Act and other Acts, and to enact measures respecting the registration of charities, in order to combat terrorism. Among these "other Acts" are the Access to Information Act, the Canadian Human Rights Act, the Personal Information Protection and Electronic Documents Act, and the Privacy Act. What is most obvious from a cursory review of the $A c t$, is the frequent occurrence of the following sentence, in order to amend the Acts mentioned above:

"The Attorney General of Canada may at any time personally issue a certificate that prohibits the disclosure of information for the purpose of protecting international relations or national defence or security."

\subsection{Critiques of Bill C-36}

The federal Information Commissioner, John Reid, in his submission to the House of Commons Standing Committee on Justice and Human Rights, notes that the Minister by issuing a certificate [3]

"would have the unfettered, unreviewable right to cloak information in secrecy for indefinite periods of time. I say "unfettered", because section 87 contains terms that are undefined and overbroad in describing when the Attorney General may properly issue a certificate. The Privacy Commissioner has suggested that the form of words used in Bill C-36 would enable the Minister to remove from the right of access the records of entire departments. I don't disagree with him that the loose wording leaves open the potential for overbroad application. And I say "unreviewable", because section 87 , by removing information covered by a certificate from the coverage of the Access to Information Act, also removes the authority of the Information 
Commissioner and the Federal Court of Canada to independently review the information to determine whether or not secrecy is justifiable".

The hard won right to make governments accountable by requiring them to release all information on request, except for specific exceptions, is now in serious jeopardy in Canada. Surely, the overriding benefit to society at large of an open and responsive government, demands strict limits on the restriction of this flow. Shortly after the terrible events of September 11, government Web sites began removing information that could possibly be used for subsequent terrorist acts. So the locations of Canadian radar stations, the types of alarms and defenses at nuclear plants, precise locations of dams, hydro (electrical energy) plants, government buildings, pipelines, and many other newly sensitive sites are examples of Web pages no longer available. The Internet will now be purged of considerable information that, in someone's opinion, could be used to further the aims of future terrorists.

The Privacy Commissioner of Canada, George Radwanski, also expressed serious reservations about the proposed legislation. Consider the following [4]:

"It is simply not acceptable, in my view, for provisions that would strip Canadians of all legally assured privacy rights to be rushed through Parliament under a cone of silence, without very specific justification and debate of their merits. Nor does it suffice to provide vague assurances that the enormous discretionary powers in question would never actually be used. We live in a country governed by the rule of law, not in a place where the authorities are endowed with unfettered power that the people must hope will only be used kindly and well".

Criticism and strong condemnation have appeared from many diverse sources. For example, the Special Senate Committee on the Subject Matter of Bill C-36 tabled its First Report on November 1. Among the many recommendations listed in the report are the following, which are particularly relevant to the present concerns [5]:

- The Committee recommends applying a five-year expiration clause - a "sunset clause - to Bill C-36.

- The Committee recommends that any such certificate [as described above] be reviewed by the Federal Court which should be specifically directed to balance the competing interests in disclosure and international relations, national defense and national security.

Let me conclude this section with the following brief criticism by the columnist, Michael Valpy [6]: 
"They [Canadian Bar Association, the Canadian Civil Liberties Association, and others] say that the Bill strips Canadians of their civil liberties. That it guts privacy and human-rights legislation, overrides Charter of Rights and Freedoms protection, puts political dissent at risk of being criminalized, gives the government and its police exorbitant powers to eavesdrop on, investigate, detain and blacklist citizens. That it's unbalanced, that it threatens the innocent".

\subsection{Amendments to Bill C-36}

The Minister of Justice, and especially the Prime Minister, had resisted widespread calls to amend the Act, for example, by including a sunset clause for some of the provisions, as well as making other changes. However, on November 21, the Justice Minister, Anne McLellan, announced a series of amendments at a hearing of the Justice and Human Rights Committee. In addition, other Acts were introduced to separate contentious issues into more manageable packages. Two of the amendments announced by Ms. McLellan follow: [7]

- Review Mechanisms: Significant powers under this Bill are subject to judicial supervision and, in many cases, this is in addition to explicit ministerial review and supervision powers. As well, the provisions in the Bill will be subject to a full review by Parliament within three years. This provision would require the Attorney General of Canada, and those of the provinces, to report publicly once a year on the exercise of the C36 powers of investigative hearings that took place under their jurisdiction. [Also on the powers of preventive arrest]

- Sunset Clause: [T]he Government will also propose that these two measures be subject to a sunset clause under which they would expire after five years. This expiry would be subject, however, to the ability of Parliament to extend the provisions, on resolutions adopted by a majority of each Chamber, for additional periods of time; but no period may ever exceed five years.

Amendments were also proposed with respect to the issuance of certificates that affect the intended operation of such acts as the Access to Information Act, the Privacy Act, and the Personal Information Protection and Electronic Evidence Act (PIPEDA). These Acts were passed after considerable effort and incorporate fundamental principles and hard won protections for individuals. Their compromise by Bill C-36 has aroused considerable concern, especially by the use of certificates to either limit the 
flow of government information or to facilitate the disclosures of personal information. In response to these criticisms, Ms. McLellan offered the following amendments, which may not serve the purpose of easing the concerns of Bill C-36 critics or, more importantly, of addressing the basic civil liberties under attack:

"I am proposing that the certificates have a maximum lifespan of 15 years, unless re-issued. After its expiry, the effect of the certificate would no longer apply and the information to which it applied would be subject to the normal provisions of the law concerning disclosure or non-disclosure.

"Further, I am proposing that the issuance of a certificate should be reviewable by a judge of the Federal Court of Appeal.

"Finally, each certificate would now be published in the Canada Gazette".

If we, the people, do not take a principled stand in opposition to many sections of Bill C-36, then indeed. the enemy is us and we all will suffer the consequences of a law that is too powerful and too overreaching. The Antiterrorism Act will shift the balance of power so necessary to a democratic society away from the legislature and judiciary and towards the bureaucracy. With these amendments, Bill C-36 was given Royal assent on December 18, 2001 .

\subsection{Computer and Specific Internet Related Issues}

The amended version of Bill C-36 contains several sections related to computers, computer networks, and Internet related issues. For a measure of completeness, it is well worth describing at least two of these. Section 320 of the Criminal Code is amended by the addition of the following section:

320.1 (1) If a judge is satisfied by information on oath that there are reasonable grounds for believing that there is material, that is, hate propaganda within the meaning of subsection $320(8)$ or data within the meaning of subsection 342.1(2) that makes hate propaganda available, that is stored on and made available to the public through a computer system within the meaning of subsection 342.1(2) that is within the jurisdiction of the court, the judge may order the custodian of the computer system to

(a) give an electronic copy of the material to the court;

(b) ensure that the material is no longer stored on and made available through the computer system; and

(c) provide the information necessary to identify and locate the person who posted the material. 
A judge is now able to make a unilateral decision on what qualifies as hate speech under the Criminal Code for material on the Internet.

The Canadian Human Rights Act is amended by the replacement of Subsection 13(2) by the following

(2) Subsection (1) does not apply in respect of any matter that is communicated in whole or in part by means of the facilities of a broadcasting undertaking but does apply to a matter that is communicated by a computer or a group of interconnected or related computers, including the Internet, or any similar means of communication.

Now, Subsection (1) refers to hate messages, that is, "any matter that is likely to expose a person or persons to hatred or contempt by reason of the fact that that person or those persons are identifiable on the basis of a prohibited ground of discrimination." Thus as a result of this amendment, the communication of hate messages by means of broadcasting systems is still not a "discriminatory practice" but doing so over the Internet is. How will Canadians be safer as a result of this amendment and why does the Internet merit such special treatment whereas traditional broadcasting media do not?

\section{THE USA PATRIOT ACT AND OTHER U.S. ACTIONS}

With the American penchant for colourful acronyms, it is not surprising that the full title of the U.S.A. PATRIOT Act [8] is 'Uniting and Strengthening America by Providing Appropriate Tools Required to Intercept and Obstruct Terrorism.' However, what may be surprising is that the text of the Act runs to some three hundred and forty-two pages, rendering a thorough analysis a rather daunting task and not one that many can claim to have undertaken. It is also worth noting that such a complex and lengthy bill was very quickly approved with very little debate.

\subsection{The Bush Administration Restricts Access to Information}

A detailed overview of the Act is not feasible but before highlighting a few of the more contentious sections related to Internet concerns, the following action taken by the U.S. government merits our attention because it will result in an active censorship of information previously available on the Internet [9]:

"Attorney General John D. Ashcroft directed agency leaders to be cautious in releasing records to journalists and others. He said agencies must "carefully consider" issues such as threats to 
national security and the effectiveness of law enforcement. Ashcroft also said agencies that legitimately turn down requests made under the Freedom of Information Act will have the backing of the Justice Department. "Any discretionary decision by your agency to disclose information protected under the FOIA should be made only after full and deliberate consideration of the institutional, commercial, and personal privacy interests" that could be implicated, Ashcroft said in a memo dated Oct. 12 and released yesterday".

\subsection{The Impact of the USA PATRIOT Act on Online Activities}

We now turn to a brief overview of the USA PATRIOT Act. Consistent with the length of this Act, the comments on just those sections that relate to online activities by the Electronic Frontier Foundation (EFF), the oldest and probably leading online civil liberties organization in the U.S., run to some twenty pages. Comments will also be taken from another online civil liberties organization, the Center for Democracy and technology. First, in what follows, selected portions taken from the Executive Summary of the EFF critique may indicate the dangers inherent in such sweeping legislation [10]:

1.Expanded Surveillance With Reduced Checks and Balances. USAPA expands all four traditional tools of surveillance -- wiretaps, search warrants, pen/trap orders and subpoenas. Their counterparts under the Foreign Intelligence Surveillance Act (FISA) that allow spying in the U.S. by foreign intelligence agencies have similarly been expanded. This means:

(a) Be careful what you put in that Google search. The government may now spy on web surfing of innocent Americans, including terms entered into search engines, by merely telling a judge anywhere in the U.S. that the spying could lead to information that is "relevant" to an ongoing criminal investigation. The person spied on does not have to be the target of the investigation. This application must be granted and the government is not obligated to report to the court or tell the person spied up what it has done.

(b) Nationwide roving wiretaps. FBI and CIA can now go from phone to phone, computer to computer without demonstrating that each is even being used by a suspect or target of an order. The government may now serve a single wiretap, FISA wiretap or 
pen/trap order on any person or entity nationwide, regardless of whether that person or entity is named in the order.

(c) ISPs hand over more user information. The law makes two changes to increase how much information the government may obtain about users from their ISPs or others who handle or store their online communications. First it allows ISPs to voluntarily hand over all "non-content" information to law enforcement with no need for any court order or subpoena. sec. 212. Second, it expands the records that the government may seek with a simple subpoena (no court review required)...

Other provisions seem to have no relation to dealing with terrorism. Suspected computer trespassers can be spied on without a prior court order and wiretaps are now allowed for suspected violations of the Computer Fraud and Abuse Act. The Center for Democracy and Technology [11] offers the following list of actions permitted under the Act that severely compromise existing civil liberties:

Allows government agents to collect undefined new information about Web browsing and e-mail without meaningful judicial review;

Allow Internet Service Providers, universities, network administrators to authorize surveillance of "computer trespassers" without a judicial order;

Overrides existing state and federal privacy laws, allowing FBI to compel disclosure of any kind of records, including sensitive medical, educational and library borrowing records, upon the mere claim that they are connected with an intelligence investigation.

The Internet presents an easy target for those concerned about opinions and views that run against current fashion. It has been subject to regular calls for the censorship of objectionable material ranging from the sexually explicit, to the hateful, to the politically extreme. In the home of the First Amendment, laws have been introduced to ban such speech; some have been declared unconstitutional, while others await judicial decision. Independent of specific legislation, major internet service providers (ISPs) have been determining the "appropriateness" of information posted by their clients, as this story illustrates [12]:

Yahoo's message boards are erupting with the kind of freeflowing, impassioned discussions the Internet's creators always dreamed of, with postings about practically every aspect of the hunt for terrorists, the capture of Kabul and mysterious plane crashes. But what's also revealing is what is being deleted. Gone are some gloating messages that say America deserved the attacks. 
Gone are some links to extremist sites promoting a jihad, or holy war, against the Western world. Gone too is a sarcastic note posted by college student Usman Sheikh: "America successfully [sic] attacks terrorists, pinpoint smart bombing," the note began, linking to pictures of bloody children who were hurt or killed as a result of the recent military raids. . . While many perceive the Internet as a public sidewalk where people are protected by federal law, it really operates more like a collection of private buildings run by forprofit businesses that have the legal right to screen their content as they please. People who come to the Web sites must obey the companies' "terms of service" agreements, which are in their simplest terms long lists of legally binding do's and don'ts. Yahoo and other companies use similar language to prohibit the posting of anything that's "unlawful, harmful, threatening, abusive, harassing, tortuous, defamatory, vulgar, obscene, libelous, invasive of another's privacy, hateful, or racially, ethnically or otherwise objectionable."

That supporters of civil liberties are on the defensive in both Canada and the U.S. is an obvious understatement. That the need is all the greater to defend these liberties in such times as we find ourselves, is the required response.

\section{CONCLUSIONS}

To indicate that the Internet continues to be a prime territory for the "war on terror," consider the following from a recent Reuters story [13] describing the possible role of search engines in discovering terrorists:

Some U.S. government officials engaged in the so-called war on terror would like to see privacy laws relaxed so that they can get better access to email and other sensitive material exchange over the Internet.

By virtue of the USA PATRIOT Act, the powers of the federal government to monitor e-mail communications has been substantially increased. As noted in a recent statement by the Free Expression Network [14],

Government investigators can now obtain court orders to monitor online communications upon an extremely low legal standard - with only a government official's assertion of relevance - and without effective judicial oversight.

Furthermore, 
... a librarian can be compelled to report what books a patron has borrowed and, if the library has computers, what Web sites he or she has visited.

It remains to be seen whether or not the Internet continues to be viewed as a dangerous medium, rife with propaganda, encrypted terrorist communication, and threatening hackers. That security measures require renewed attention has long been known but that increased surveillance of Internet communication will improve overall security is an unproven and potentially dangerous proposition.

There is much more but the idea is clear. The events of September 11, 2001 have served to initiate a grand assault on civil liberties presumably in order to enable governments, more specifically law enforcement officials and intelligence agencies, to protect us and our institutions from the all too powerful forces of international terrorism. In no sense do I wish to be seen as trivializing the tragic loss of lives that occurred on that by now memorable day but the loss of vitally important civil liberties as a result, with no fixed period for review and retraction does not seem an appropriate way to recognize that tragedy, or to preserve our freedoms. What are we as a society if we do not value above all our exercise of and commitment to fundamental democratic principles? The challenge is to defend these principles, publicly and vigorously, now and into the foreseeable future. We owe our children and our country nothing less.

\section{Endnotes}

1 Second reading took place on November 24, 2001and included amendments announced by the federal government on November 20 . These amendments can be found at the Web page with URL: http://canada.justice.gc.ca/en/news/sp/2001/doc_27900.html The amended version of the Act is available at the Web page with URL: http://www.parl.gc.ca/PDF/37/1/parlbus/chambus/house/bills/government/C36_2.pdf and the final version given Royal Assent is available at URL: http://www.parl.gc.ca/PDF/37/1/parlbus/chambus/house/bills/government/C$\underline{36 \quad 4 . p d f}$

\section{REFERENCES}

1. Brennan, Jr., W. J. (1987) The Quest to Develop a Jurisprudence of Civil Liberties in Times of Security Crises. Available from the Web page with URL: http://www.brennancenter.org/resources/downloads/nation security brennan.pdf

2. Bill C-36 (2001) The Anti-terrorism Act,_Available from the Web page with URL: http://www.parl.gc.ca/PDF/37/1/parlbus/chambus/house/bills/government/C-36 1.pdf 
3. Reid, J. (2001) Remarks to the House of Commons Standing Committee on Justice and Human Rights (Bill C-36), Octoben 23. Available from the Web page with URL: http://www.infocom.gc.ca/speeches/speeches view details-e.asp

4. Radwanski, G. (2001) News Release. November 21. Available from the Web page with URL: http://www.privcom.gc.ca/media/nr-c/02 05 b 011121 c.asp

5. Special Senate Committee (2001) First Report on the Subject matter of Bill C-36, November 1. Available from the Web page with URL: http://www.parl.gc.ca/37/1/parlbus/commbus/senate/com-e/sm36-e/rep-e/rep01oct01-e.htm

6. Valpy, M. (2001) Burn this Bill, The Globe and Mail, October 27.

7. McLellan, A. (2001) Notes for the Minister of Justice, Appearance before the House of Commons Standing Committee on Justice and Human Relations, Bill C-36, November 20.

Available from the Web page with URL: http://canada.justice.gc.ca/en/news/sp/2001/doc 27900.html

8. USA Patriot Act (2001). Available from the Web page with URL: hllp://www.epic.org/privacy/terrorism/hr3162

9. Ashcroft Urges Caution with FOIA Requests (2001) Associated Press, Washington Post, October 17, p. A15.

10. Electronic Frontier Foundation (2001) EFF Analysis of the Provisions of the USA Patriot Act That Relate to Online Activities, October 31. Available from the Web page with URL: http://www.eff.org/Privacy/Surveillance/Terrorism_militias/20011031_eff_usa_patriot anal ysis.html

11. Center for Democracy and Technology (2001) CDT Policy Post Volume 7, Number 11, October 26. Available from the Web page with URL: http://www.cdt.org/publications/pp 7.11.shtml

12. Cha, A. E. (2001) Screening Free Speech? Washington Post, November 18, p. H01.

13. Can Search Engines Track Down Terrorists (2002). Reuters, April 17. Available from the Web page with URL: http://zdnet.co.com/2100-1105-885415.html

14. Free Expression Network (2002). The USA Patriot Act Six Months Later: A Statement by Members of the Free Expression Network, April 22. Available from the Web page with URL: http://www.frecexpression.org/patriotstmt.stm 